\title{
15 \\ PENYEBARAN RADIKALISME DI MEDIA PENYIARAN TV INDONESIA
}

\author{
Ah. Fajruddin Fatwa \\ Dosen Fakultas Syariah dan Hukum UIN Sunan Ampel Surabaya \\ fajruddin@uinsby.ac.id
}

\begin{abstract}
This article focused on assessing the role of media broadcasting in the spreading religious radicalism in Indonesia. The emergence of numbers broadcasting and diversity of content used was not only have positive impact on the delivery of information in the community but also possible negative impact among the communities. The research found three identified negative impacts among society. First, spreading hatred information towards certain social or religious groups. Second, the potential for disintegration of national disintegration with messages that conflict with national values. Third, the potential for legal violations that occur due to the weak supervision of digital-based broadcast content. The research also found three weaknesses to develop the capacity Indonesia Broadcast committee first, restoring the weak of statement regulation and contradictory norm within the Broadcasting Behavior Guidelines and broadcasting behavior standard. Second, Developing the institutional coordination among the state institution, and strengthening the socialization of new Broadcasting Behavior Guidelines and broadcasting behavior standard.
\end{abstract}

Keywords: Media radicalism, broadcasting industry, KPI, P3SPS.

\begin{abstract}
Abstrak: Artikel ini difokuskan pada penilaian peran penyiaran media dalam menyebarkan radikalisme agama di Indonesia. Munculnya jumlah penyiaran dan keragaman konten yang digunakan tidak hanya berdampak positif pada penyampaian informasi pada komunitas tetapi juga kemungkinan dampak negatif di antara komunitas. Penelitian ini menemukan tiga dampak negatif yang diidentifikasi di antara masyarakat. Pertama, menyebarkan informasi kebencian terhadap kelompok sosial atau agama tertentu. Kedua, potensi disintegrasi disintegrasi nasional dengan pesan-pesan yang bertentangan dengan nilai-nilai nasional. Ketiga, potensi pelanggaran hukum yang terjadi akibat lemahnya pengawasan konten siaran berbasis digital. Penelitian ini juga menemukan tiga kelemahan untuk mengembangkan kapasitas komite Siaran Indonesia terlebih dahulu, memulihkan lemahnya peraturan pernyataan dan norma kontradiktif dalam Pedoman Perilaku Penyiaran dan standar perilaku penyiaran. Kedua, mengembangkan koordinasi kelembagaan di antara lembaga negara, dan memperkuat sosialisasi Pedoman Perilaku Penyiaran baru dan Standar Perilaku Penyiaran.
\end{abstract}

Kata Kunci: Radikalisme media, industri penyiaran, KPI, P3SPS. 


\section{A. Dinamika Kontemporer Industri Penyiaran Indonesia}

Revolusi Industri Ke IV pelan tapi pasti mencapai puncak inevitable movement yang harus dihadapi oleh dunia penyiaran. Dunia penyiaran tradisional tidak lagi mampu berbangga diri dengan kemampuan modal, ketersediaan SDM penyiaran, dan perlindungan hukum yang dimilikinya. Dunia penyiaran tradisional terancam dengan ditemukannya beragam media baru penyiaran digital yang berkembang pesat di masyarakat. Siaran televisi dan radio bukan lagi rujukan pertama dan utama perolehan berita dan informasi karena beragam media berbasis digital telah berhasil mengurangi signifikansi konsep tradisional media penyiaran. Laporan survey Delloite menyatakan bahwa pada saat prime time penyiaran, masyarakat lebih memilih menggunakan media sosial dibandingkan menyaksikan televisi. ${ }^{354}$

Tantangan dunia penyiaran global ternyata memiliki imbas pada dunia penyiaran Indonesia.Walau memiliki perbedaan demografi dan segmentasi, dunia penyiaran Indonesia juga mengalami kendala strategis kondisi penyiaran. Mulai kendala abadi teknis keterbatasan pita frekwensi, kapitalisasi modal pada stasiun tertentu, afiliasi social politik hingga mengecilnya pangsa penyiaran. Masyarakat Indonesia mulai terbagi dalam dua viewer utama. Pertama, kalangan perkotaan menengah yang lebih memilih menjadi pelanggan tv berlangganan dan/atau pelanggan TV komunitas. Kedua, kalangan millennial yang lebih memilih menggunakan media penyiaran interaktif social media. ${ }^{355}$ Lonjakan pengguna media social yang menyediakan konten penyiaran malah memunculkan idola dan lapangan kerja baru.

Perubahan kondisi penyiaran di atas sudah tentu bukan hanya disebabkan kemudahan akses teknologi dan perangkat media penyiaran, melainkan juga munculnya kondisi antagonistik antara masyarakat sebagai pengguna jasa vis-à-vis kalangan industri sebagai penyedia jasa penyiaran. Masyarakat tidak lagi memiliki fanatisme dan konsistensi akses pada stasiun televisi atau radio tertentu. Mereka memilih program media sosial, dan media digital sebagai penyuplai informasi yang dibutuhkan. Sebaliknya, beragam nilai rating tidak mampu meyakinkan industri penyiaran akan keberlangsungan siarannya. Jarak hubungan antara masyarakat dengan industri penyiaran terlihat dari penyebaran berita via media sosial, dan youtube yang lebih cepat dibandingkan beritaberita televisi atau radio. ${ }^{356}$ Cristian Zilles menyebut istilah viral, trending, dan buzz worthy lebih signifikan pengaruhnya dibandingkan skala rating tradisional. ${ }^{357}$

Kondisi hubungan antagonistik antara masyarakat sebagai pemirsa dengan industri penyedia jasa penyiaran ternyata bukan selesai pada masalah akses semata, melainkan juga munculnya problem baru yang mulai terasa mengganggu eksistensi Pasal 3 UU 32 Tahun 2002 tentang Penyiaran. Tujuan penyelenggaraan penyiaran adalah untuk memperkukuh integrasi nasional, terbinanya watak dan jati diri bangsa yang beriman dan bertakwa, mencerdaskan kehidupan bangsa, memajukan kesejahteraan umum, dalam rangka membangun masyarakat yang mandiri, demokratis, adil dan sejahtera, serta menumbuhkan industri penyiaran Indonesia. ${ }^{358}$

Tujuan luhur yang telah disepakati DPR dalam perundangan penyiaran menemukan kondisi baru tentang mulai merebaknya konten LGBT, konten kekerasan, pornografi, radikalisme, dan mistik dalam dunia penyiaran. Segala bentuk Konten penyiaran yang bertentangan dengan Pancasila, UUD NRI tahun 1945, UU penyiaran dan norma luhur bangsa Indonesia tentu harus dicegah, ditolak dan dikurangi durasi penayangannya dalam ranah siaran publik. Penolakan ini

\footnotetext{
354 Sejak 2013, laporan menyebutkan pemirsa lebih memilih menggunakan media digital dibandingkan media tradisional. https://www2.deloitte.com/content/dam/Deloitte/global/Documents/ConsumerBusiness/gx-cb-thl-facebook-digital-channels-travel.pdf

355 Dampak media social bagi kalangan millennial dapat ditemukan dalam karya Agung Prabowo dan Kurnia Arofah, "Media Sosial Instagram Sebagai Sarana Sosialisasikebijakan Penyiaran Digital" dalam Jurnal ASPIKOM, Volume 3 Nomor 2, Januari 2017, hlm 256-269

356 Sherice Gearhart and Seok Kang, Social Media in Television News: The Effects of Twitter and Facebook Comments on Journalism, Electronic News, 2014, Vol. 8(4) 243-259

357 Cristian ZIlles, Social Media Has Forever Changed The Way We Consume News dalam https://socialmediahq.com/social-media-forever-changed-way-consume-news/

358 Periksa Pasal 3 UU no 32 tahun 2002 tentang penyiaran
} 
sudah tentu terbatas pada konten siaran semata tanpa mengurangi hak asasi manusia yang telah dimiliki oleh warga negara. 359

Gejala peningkatan radikalisme yang terjadi di masyarakat sudah tentu bukan hadir dalam ruang kosong melainkan lahir dengan adanya rentang waktu, ruang ekspresi, dan media penyebarannya. Kajian kali ini akan memberikan analisis bagaimana Komisi penyiaran Indonesia memiliki peran strategis dalam membatasi dan menghilangkan radikalisme di masyarakat dengan memkasimalkan peran yang dimilikinya serta konsolidasi potensi hukum yang telah ada.

\section{B. Konsepsi Dasar Radikalisme}

Kajian tentang radikalisme di Indonesia bukanlah hal baru, beragam prespektif akademik telah memberikan narasi tentang radikalisme. Walupun demikian, klausula hukum yang tegas tentang makna radikalisme sulit ditemukan. Klausula unsure-unsur subjektif dan objeksif radikalisme tidak ditulis dan dirumuskan dengan tegas. Oleh sebab itu, merumuskan klausula radikalisme membutuhkan banyak perenungan jalinan norma yang bertebaran dalam ketentuan hukum yang beragam.

Radikalisme dalam optik kebahasaan memiliki beragam makna. Referensi daring KBBI memberikan tiga makna berbeda. Radikalisme adalah paham atau aliran yang radikal dalam politik; paham atau aliran yang menginginkan perubahan atau pembaharuan sosial dan politik dengan cara kekerasan atau drastis; sikap ekstrem dalam aliran politik. ${ }^{360}$ Makna verbatim di atas tentu tidak memadai jika digunakan memahami radikalisme dalam prespektif Hukum. Hukum pidana sejak awal memberikan batasan tegas bahwa nullum delichtum noella poena siena lege poenali, sebuah perbuatan hukum baru dapat disebut sebagai sebuah kesalahan apabila ada ketentuan tertulis (lex scripta) batasan kepastian (lek certa) pelaku telah cukup usia dan terbukti memiliki niat melakukan kejahatan (mens rea).

Keterbatasan makna verbatim yang diberikan oleh KBBI tersebut ternyata bukan hanya terjadi dalam ranah keindonesiaan. Kajian makna radikalisme, walaupun sudah lama dilakukan juga memiliki dinamika menarik dalam memahaminya.

Radikalisme seringkali dipahami sebagai paham pemikiran yang dibuat-buat oleh sekelompok orang yang menginginkan adanya suatu perubahan kondisi sosial, politik, atau keagamaan yang terjadi secara drastis dengan menggunakan cara-cara kekerasan. Dalam prespektif BNPT, Radikalisme dianggap sebagai embrio utama lahirnya terorisme. Radikalismeadalah suatu sikap yang mendambakan perubahan secara total dan bersifat revolusioner dengan menjungkirbalikkan nilai-nilai yang ada secara drastis lewat kekerasan (violence) dan aksi-aksi yang ekstrem. BNPT juga memberikan perincian bahwa radikalisme dapat dikenali dengan mempertimbangkan 4 sikap yang ditunjukkan seseorang yaitu 1) intoleran (tidak mau menghargai pendapat \&keyakinan orang lain), 2) fanatik (selalu merasa benar sendiri; menganggap orang lain salah), 3) eksklusif (membedakan diri dari umat Islam umumnya) dan 4) revolusioner (cenderung menggunakan cara-cara kekerasan untuk mencapai tujuan). ${ }^{361}$

Thomas Koruth Samuel memberikan penjelasan kendala memahami radikalisme dalam dua hal. Pertama, tidak ada optik juridis tunggal yang dapat digunakan dalam memahami radikalisme. Kedua, penegak hukum masing-masing Negara memiliki pemahaman berbeda sesuai dengan respon hukum yang diberikan pada masalah radikalisme.Samuel memberikan contoh perbedaan yang terjadi antara Denish security and intelegent service (P.E.T) dengan US Department of Homeland security (DHS). P.E.T memahami radikalime sebagai sebuah proses perbuatan terorisme yang dilakukan seseorang dan bertentangan dengan nilai-nilai demokrasi, untuk mencapai tujuan poltik atau idiologi tertentu. Sebaliknya, DHS memberikan makna radikalisme adalah proses

359 Penjelasan posisi LGBT dalam HAM Indonesia dapat dilihat dalam tulisan Meilanny Budiarti Santoso, LGBT Dalam Perspektif Hak Asasi Manusia, Social Work Jurnal Volume: 6 Nomor: 2 Halaman: 154 - 272.

360 Sila baca https://kbbi.web.id/radikalisme diakses tanggal 1 Juli 2019

361 BNPT, Strategi Menghadapi Paham Radikalisme Terorisme - ISIS dalam https://belmawa.ristekdikti.go.id/wp-content/uploads/2016/12/Strategi-Menghadapi-PahamRadikalisme-Terorisme.pdf diakses tanggal 1 Juli 2019 
menerima pemahaman system pemikiran extrimist, termasuk diantaranya kemauan untuk menggunakan, mendukung, dan memfasilitasi terjadinya kekerasan agar memiliki dampak terjadinya perubahan sosial. ${ }^{362}$

Konstruksi ontologis tiga definisi radikalisme di atas ternyata memiliki 3 persamaan utama. Pertama, radikalisme adalah perbuatan yang menginginkan adanya perubahan dengan cepat. Kedua, radikalisme menggunakan bentuk-bentuk perbuatan yang bertentangan dengan norma hukum dan demokrasi. Ketiga, radikalisme ramah dan toleran dengan penggunaan nilai nilai kekerasan.

Dinamika perbedaan pandangan radikalisme juga terjadi dalam kajian hukum Islam. radikalisme dalam pandangan Muhammad Madani dan Muthi' Allah adalah perbuatan yang melampaui batas. Radikalisme seringkali disandingkan dengan dengan kata al ghuluw wa Tat\}aruf yang bermakna berlebihan dan melampaui batas kewajaran. ${ }^{363}$ Madani menggunakan ketentuan menyatakan bahwa radikalisme bertentangan dengan ajaran hukum Islam dan gagasan awal pelaksanaan hukum Islam. Ajaran Islam harus disebarkan dengan jalan kelembutan dan kesantunan dan gagasan awal kehadiran Islam adalah memberikan perdamaian dan keselamatan.

Madani tidak hanya memberikan kecaman keras dan doktrin hukum tentang radikalisme. Ancaman radikalisme dijabarkan dengan memberikan geneologi awal kemunculan radikalisme. Dampak penolakan terhadap model penyelesaian sengketa legalitas kepemimpinan Ali> ibn Abu> T\}a $>$ lib yang dilakukan oleh golongan syi'ah dan khawarij adalah titik awal kajian radikalisme dalam hukum Islam. Kedua golongan tersebut bukan hanya memusuhi pemerintahan dan meninggalkan gagasan damai dalam menyelesaikan masalah melainkan juga memiliki gagasan menyimpang dari hukum Islam, yaitu kebolehan membunuh khalifah dan memerangi pemerintahan guna mencapai tujuan politiknya. ${ }^{364}$

Muthi'Allah memberikan pandangan menarik tentang perbedaan prinsip antara kata al ghuluw dan al Tat\}aruf ketika disandingkan dengan ajaran hukum Islam. al ghuluw memiliki makna melampaui batas dari gagasan dasar pelaksanaan hukum Islam sedangkan Tat\}aruf artinya penyimpangan dan distorsi ajaran hukum Islam. Selain menggunakan kata al ghuluw wa Tat\}aruf Mut\}i juga menggunakan istilah lain yaitu tanat\}u yang bermakna pemahaman berlebihan atas gagasan awal hukum Islam. 365

Thalib memberikan penjelasan lain tentang penyebab radikalisme. Awalnya, radikalisme dianggap sebagai konsekwensi positif dalam bentuk gerakan pembaharuan pemikiran (tajdi $>d$ ), rekonsiliasi sengketa (Isla>h\}) hingga perang yang digunakan untuk mengembalikan kejayaan Islam. BIbit radikalisme klasik ini ternyata juga mempengaruhi pola perkembangan radikalisme Islam modern. Kondisi kemajuan barat dalam bidang teknologi dan pengetahuan dianggap terlalu dominan dalam menghegomoni kuasa sosial, ekonomi, dan politik Negara-negara Islam. ${ }^{366}$

Radikalisme adalah perbuatan yang terlarang dan masuk dalam jenis jinayah ta'dzir yang memberikan kuasa kepada hakim untuk memberikan keputusan sesuai dengan sumber hukum yang telah disepakati dan tidak bertentangan dengan sumber hukum utama, al Quran dan al Hadits. Namun bila dilihat dari sudut pandang keagamaan dapat diartikan sebagai paham keagamaan yang mengacu pada fondasi agama yang sangat mendasar dengan fanatisme keagamaan yang sangat tinggi, sehingga tidak jarang penganut dari paham atau aliran tersebut menggunakan kekerasan

362 Samuel, Thomas Koruth, 1977-RADICALISATION IN SOUTHEAST ASIA: A SELECTED CASE STUDY OF DAESH

IN INDONESIA, MALAYSIA AND THE PHILIPPINES, (Kula Lumpur; The Southeast Asia Regional Centre for Counter-Terrorism (SEARCCT), Ministry of Foreign Affairs, 2016), 6-8

363 Sila baca inkonsitensi penyandingan radikalisme dengan kata al Ghuluw al al Tat\}arüf dalam Muh\}ammad Madani Būsaq', H\}ukm al Islamm fi al Ghuluw wa al tat\}arrüf, (Riyad; tt, 2012), 6-8

364 Ibid., 10-16

365 Mut\}i Alla, Al Ghuluw Wa Tat\}aruf Fĩ al DiN, (Jeddah; munqahah wa muhakkamah, 2017) 10-15

366 Nur Jannah, Faktor Pemicu Munculnya Radikalisme Atas Nama Dakwah, Jurnal Dakwah dan Ilmu Komunikasi Vol.XIV NO 2 tahun 2013. 257-258 
pada orang yang berbeda paham atau aliran untuk mengaktualisasikan paham keagamaan yang dianut dan dipercayai untuk diterima secara paksa

\section{Radikalisme dalam Bingkai Perundangan Indonesia}

Walaupun secara tegas ruang lingkup klausula radikalisme sudah memiliki pijakan hukum. Klausula lengkap radikalisme tidak ditemukan secara tertulis dalam ketentuan hukum Indonesia. Ketentuan hukum yang seringkali dianggap sebagai rujukan pertama dan utama adalah ketentuan UU No.15 Tahun 2003 tentang Pemberantasan Tindak PidanaTerorisme. Ketentuan perundangan ini dalam disebutkan: Setiap orang yang dengan sengaja menggunakan kekerasan atau ancaman kekerasan menimbulkan situasi teror atau rasa takut terhadap orang secara meluas atau menimbulkan korban yang bersifat massal, dengan cara merampas harta benda orang lain, atau mengakibatkan kerusakan atau kehancuran terhadap obyek-oyek vital strategis atau lingkungan hidup atau fasilitas publik atau fasilitas internasional.

\section{Optimalisasi Peran dan Penguatan Kelembagaan}

Peluang Komisi Penyiaran Indonesia (KPI) mendorong terciptanya industri kreatif penyiaran terkesan kurang optimal dalam tugas keseharian KPI. KPI seringkali berlindung atas nama kompetensi UU untuk menjalankan fungsinya dengan memalingkan muka atas peluang yang dimilikinya menanggapi perubahan besar model dan standar penyiaran. Lembaga ini terkesan sebagai lembaga penerima aduan masyarakat dan pemberi hukuman bagi pelanggaran standar penyiaran. Peran ini tentu tidak salah karena kewajiban KPI dalam pasal 8 ayat tiga huruf A dan E memang menyatakan demikian. Tugas dan kewajiban KPI antara lain menjamin masyarakat untuk memperoleh informasi yang layak dan benar sesuai dengan hak asasi manusia; serta menampung, meneliti, dan menindaklanjuti aduan, sanggahan, serta kritik dan apresiasi masyarakat terhadap penyelenggaraan penyiaran.

Pemahaman Legalistik-positivistic di atas berdampak pada kinerja informasi dan produktivitas kelembagaan KPI. Misalnya, laman KPI seringkali menawarkan tiga hal saja, berita sanksi, sosialisasi regulasi, dan pengumuman serta kegiatan kedinasan saja. Lihat saja, kajian tentang literasi media dan dunia penyiaran sangat rendah. ${ }^{367}$ Padahal, KPI seharusnya mampu menggunakan peluang strategis yang diamanatkan dalam Pasal 52 UU 32 Tahun 2002 tentang Penyiaran. Klausul pasal tersebut menyatakan bahwa setiap warga negara Indonesia memiliki hak, kewajiban, dan tanggung jawab dalam berperan serta mengembangkan penyelenggaraan penyiaran nasional.

Klausul pasal tersebut seandainya dipahami dengan logika power cube tentu mampu mengoptimalkan peran KPI dalam levels, spaces and forms of power, and their interrelationship. Perubahan masyarakat seharusnya tidak hanya didekati dengan pendekatan legal melainkan juga melalui optimalisasi peran-peran advokasi sosial dan jaringan kerja sama kelompok masyarakat yang dilakukan. Pendekatan ini juga memiliki nilai lebih dalam mengakselerasi penerimaan perubahan sosial yang diharapkan. ${ }^{368}$

Partisipasi masyarakat bisa digerakkan KPI melalui dua ranah yang berbeda yaitu kemunculan apresiasi KPI atas produktivitas dan kreativitas lembaga penyiaran dalam mendorong terciptanya industri peyiaran. Beragam produk lembaga penyiaran swasta yang menyasar pengembangan keahlian penyiaran misalnya Eagle awards, metro TV, liputan 6 masuk kampus SCTV, atau kelana kota suara Surabaya terbukti memiliki potensi pengembangan industri kreatif masyarakat. Kesadaran publik untuk berpartisipasi merupakan prasyarat demi meningkatkan

\footnotetext{
${ }^{367}$ Hanya terdapat 17 data penyiaran dan 32 data literasi media. Arsip lebih dominan pada berita kedinasan http://kpi.go.id/index.php/id/lihat-arsip-terkini

368 John Gaventa, Finding the Spaces for Change: A Power Analysis, Handbook of social advocacy, Coady International school, 2013
} 
kualitas media. Tanpa partisipasi publik, regulator harus berusaha sendirian dalam melawan dominasi industri media. Untuk memperbaiki situasi ini, kemelekan media harus ditingkatkan. ${ }^{369}$

Produktivitas dan kreativitas masyarakat adalah nilai tawar yang harus diperjuangkan oleh KPI. Perjuangan nilai tawar sudah tentu bukan hanya memanjakan diri melalui jalur kompetensi legal yang dimilikinya, melainkan juga memerankan diri secara langsung melindungi kepentingan masyarakat yang berhak di ruang publik dan konsolidasi intensif membangun kerja sama dengan beragam lembaga negara misalnya Komisi 1 DPR RI, dan jaringan masyarakat lain yang memiliki kepentingan memajukan industri penyiaran. Eko Sulistiyo, Deputi Komunikasi Politik Kantor Staff Kepresidenan, menyebutkan "kebijakan media dianggap telah gagal untuk mengatur penyiaran sebagai sebuah industri. Pembuat kebijakan dan negara sebagai regulator gagal memberikan pembatasan yang jelas antara monopoli dan oligopoli. Absennya kebijakan khusus untuk mengatur aspek komersial dari penyiaran ini menjadi faktor ekspansi dan konglomerasi media penyiaran." 370

Peluang KPI yang kedua adalah edukasi langsung pada masyarakat tentang standar penyiaran melalui media KPI. Kebijakan ini berbeda dengan sosialisasi yang hanya berkutat pada ruang kecil komunitas penyiaran semata. Akan tetapi, kebijakan tersebut lebih pada penjaringan calon pengguna penyiaran dengan melakukan beragam kunjungan langsung atau lomba-lomba penyiaran yang digagas KPI. Untuk memberikan edukasi, idealnya laman KPI berisi hal-hal produktif tentang ilmu penyiaran, lomba-lomba atau menjadi kepanjangan komunitas dalam melakukan pengembangan industri penyiaran. Seandainya KPI mampu membuat agenda tahunan film pendek tentang pembangunan nasional, tempat wisata, atau lomba lain level pelajar, KPI tentu akan menjadi lembaga harapan dan kebanggaan kreativitas remaja dan anak-anak.

Peluang edukasi juga dilakukan dengan apresiasi positif atas kinerja masyarakat untuk mengkampanyekan hal-hal positif penyiaran. Misalnya, apresiasi atas komunitas jangan telanjang depan kamera yang secara signifikan menekan kuantitas siaran pornografi, kemudian laman NU, Muhammadiyah dan lembaga keagamaan lain yang bekerja keras mengenalkan konsep Islam rahmatan lil alamin yang berkemajuan, menyebarkan nilai kemanusian, serta siaran keluhuran pekerti bangsa.

Peluang lain KPI adalah merumuskan pola strategis perlindungan nilai-nilai kebangsaan dan keragaman. Stasiun televisi selama ini memang terlihat sangat memberikan ruang siaran keagamaan. Walaupun demikian, patut dipertanyakan tentang komitmen penguatan kebangsaan yang harus dilakukan KPI sebab siaran tentang sosio-demografi, ragam budaya, atau nilai-nilai luhur lainnya nyaris terdesrupsi dengan nilai keuntungan dan nilai rating yang dikehendaki.

Padahal, keduanya bukanlah hal yang berlawanan arah. Lihat saja, rating dialog motivasi ala Kick Andy, Mata Najwa, Si Bolang, Sopo Jarwo dan beragam konten lain yang lebih digemari masyarakat dibandingkan siaran-siaran kebencian, mistik, dan sinetron manja semata. Sayangnya, beragam acara tersebut tidak menyentuh, setidaknya kurang menyentuh, kalangan pelajar yang akan menjadi calon pengguna penyiaran. Kalangan pelajar dibiarkan terlarut dengan aktivitas media digital tanpa adanya partisipasi aktif lembaga penyiaran.

Peluang lain yang seharusnya dilakukan oleh KPI adalah memaksimalkan kewajiban pemilik media dalam memberikan acara yang memberikan kontribusi positif bagi pembangunan dan menegakkan aturan hukum. Hingga saat ini beragam tayangan televisi umum maupun kabel yang berisi sexualitas, kekerasan, dan penyimpangan mampu diakses keluarga Indonesia dengan paket standar termurah. Kebijakan parental control tidak banyak melindungi nilai-nilai kebangsaan dan keragaman. Acara 90 days fiancés; before a after, first dating, naked and afraid, tidak mampu difilter oleh kebijakan parental control karena dikenali sebagai acara drama sabun semata.

\footnotetext{
${ }^{369}$ Yanuar Nugroho, (et.All), Memetakan Kebijakan Media di Indonesia, Centre for Innovation Policy and Governance, VIII

370 Eko Sulistiyo, Konglomerasi Media dan Revisi UU Penyiaran, Kompas 1 April 2017, berita senada juga periksa http://ksp.go.id/konglomerasi-media-dan-revisi-uu-penyiaran/
} 
Langkah strategis mewajibkan acara yang berkontribusi positif bagi pembangunan adalah bagian dari khittah KPI dan solusi legal dalam melindungi kepentingan masyarakat. Selain menunggu proses revisi undang-undang penyiaran, langkah kewajiban edukasi adalah solusi penting menunjukkan eksistensi KPI dalam dunia penyiaran.

\section{E. Independensi dan Koordinasi Kelembagaan}

Kompetensi dan agenda KPI yang telah diamanatkan undang-undang sudah tentu bukan hal yang mudah dilakukan. Selain kewajiban taat, tunduk dan patuh kepada undang-undang penyiaran. Rumusan Pasal 3 Undang-Undang Nomor 28 Tahun 1999 Tentang Penyelenggaraan Negara Yang Bersih dan Bebas dari Korupsi, Kolusi dan Nepotisme juga harus diperhatikan oleh komisionernya. Penyalah gunaan kewenangan bukan hanya sebatas sesuatu yang disadari dan dihindari melainkan juga harus diwujudkan dalam langkah-langkah kebijakan strategis agar tidak terjadi penyimpangan asas hukum, asas penyelenggaraan Negara yang baik dan tujuan atau maksud dari suatu pemberian kewenangan undang-undang

Selain masalah kemampuan melaksanakan kompetensi dan agenda KPI, koordinasi kelembagaan adalah keniscayaan yang harus dilakukan lembaga KPI dalam melaksanakan tugasnya. Selain karena beragam aturan penyiaran terakomodasi secara explisit dalam jejaring legal dictum hukum lainnya, beragam kompetensi KPI tereduksi dengan lahirnya ketentuan hokum baru yang menjadi memorie van toelichting peraturan sebelumnya. Dalam masalah kepemilikin media misalnya, Pembatasan kepemilikan dan penguasaan Lembaga Penyiaran Swasta (LPS) oleh satu orang atau satu badan hukum, baik di satu wilayah siaran maupun di beberapa wilayah siaran, sebagaimana diatur dalam Undang-Undang Penyiaran dinyatakan konstitusional oleh Mahkamah Konstitusi. Ketentuan ini dimuat dalam Putusan No. 78/PUU-IX/2011. Dalam prespektif putusan MK setebal 718 halaman tersebut menyatakan bahwa Pengalihan saham perseroan yang demikian dapat dibenarkan sepanjang tidak melebihi batas kepemilikan dan penguasaan LPS sebagaimana diatur dalam peraturan perundang-undangan yang berlaku. ${ }^{371}$

Tulisan Arsam dalam sebuah jurnal secara langsung menyebutkan bahwa praktik oligopoly kepemilikan media dan kebijakan Negara memberikan data menarik jejaring kepemilikian silang media. ${ }^{372} \mathrm{Hal}$ senada juga disampaikan oleh Yanuar yang menyatakan media UU Penyiaran dan KPI saat ini tidak memiliki kuasa mengontrol kepemilikan media, meski memuat klausul kepemilikan silang (Pasal 18), UU tersebut tidak efektif dalam mencegah aglomerasi atau pemusatan kepemilikan media seperti yang terjadi saat ini. Beragam peraturan media dan penyiaran bukan hanya saling terkait, terkadang norma yang telah ditetapkan DPR tereduksi dengan munculnya Peraturan pemerintah. Yanuar memberikan jejaring norma media dan penyiaran sebagaimana bagan berikut. ${ }^{373}$

\footnotetext{
${ }^{371}$ https://mkri.id/index.php?page=web.Berita\&id=7581 diakses tanggal 30 Juni 2019 pukul 20.00

372 Arsam, oligopoly kepemilikan media dan kebijakan Negara dalam AT-TABSYIR, Jurnal Komunikasi Penyiaran Islam, tt, tp, 149

373 Bagan verbatim di atas diambil dari Yanuar (et.all), memetakan kebijakan media di Indonesia, CIPG. 92
} 


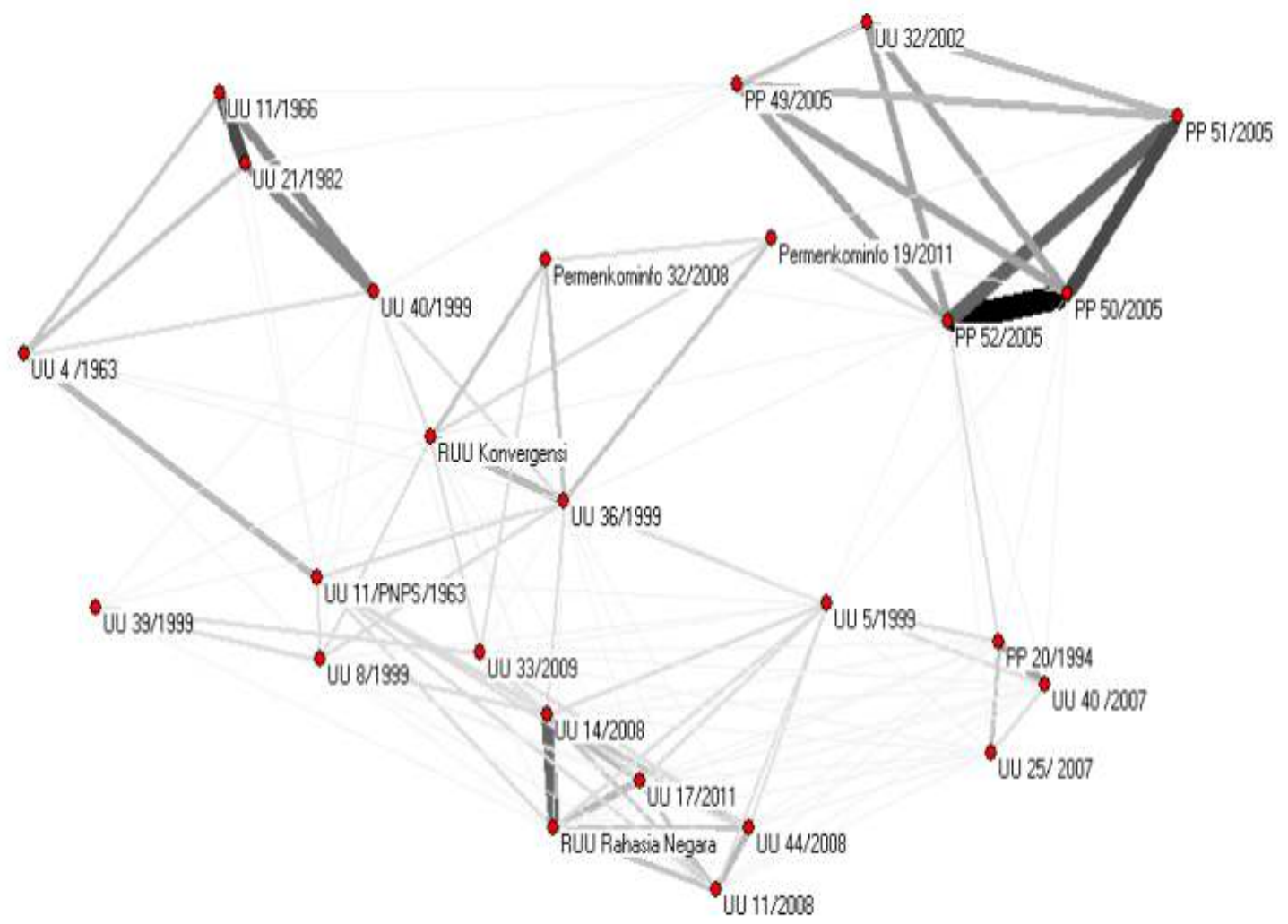

KPI sebagai lembaga pengawas siaran idealnya mengambil sikap konsisten dengan tupoksi yang dimiliki untuk mengawasi konten siaran, memastikan hak masyarakat atas ketersediaan siaran sehat yang informative dan menegakkan aturan secara konsisten. Perdebatan pasal 18 ayat 1 tentang Pemusatan kepemilikan dan penguasaan Lembaga Penyiaran Swasta oleh satu orang atau satu badan hukum, baik di satu wilayah siaran maupun di beberapa wilayah siaran dibatasi. Sedangkan norma pasal 34 ayat 4 berbunyi 'Izin Penyelenggaraan Penyiaran dilarang dipindahtangankan kepada pihak lain berikut dengan diskursus resiko penguasaan media selesai dengan lahirnya putusan MK tersebut.

\section{F. Formulasi Strategis Advokasi Peran KPI}

Hal penting yang perlu disoroti terkait formulasi KPI sekarang adalah tupoksi KPI dan KPID yang masih tumpang tindih. Dalam Pasal 7 UU 32 Tahun 2002 tentang Penyiaran disebutkan, KPI dibentuk di tingkat pusat dan di tingkat daerah. Berdasarkan hal tersebut, maka dapat dilihat bahwa susunan kelembagaan KPI Pusat dan KPID bersifat koordinatif. Meskipun demikian, KPI dan KPID memberikan sanksi administratif secara terpisah kepada lembaga penyiaran yang melakukan pelanggaran. Jadi sanksi yang diterima oleh lembaga penyiaran tersebut ada 2 yaitu yang berasal dari KPI dan juga dari KPID. ${ }^{374} \mathrm{Hal}$ ini tentu saja dapat memberatkan lembaga penyiaran yang mendapatkan sanksi tersebut dan terkesan tidak efektif. Fungsi koordinatif seharusnya dapat diimplementasikan sehingga sanksi administratif yang dikeluarkan tersebut berdasarkan hasil mufakat KPI dan KPID. Tidak terbatas pada sanski administratif, kebijakan KPI dan KPID harus singkron dan satu semangat mewujudkan tujuan bersama sebagaimana dalam UU Penyiaran.

374 Denico Doly, “Upaya Penguatan Kelembagaan Komisi Penyiaran Indonesia Dalam Perspektif Hukum, ” Negara Hukum: Membangun Hukum untuk Keadilan dan Kesejahteraan Vol. 6, No. 2 Desember 2015, (149167). H. 160. 
Sebuah artikel menarik yang berjudul, succeeding in the age of digital transformation keluaran Deloite Insight mungkin bisa dijadikan modal dasar optimaliasi peran KPI di era digital. Peran KPI maupun KPID yang bertindak sebagai lembaga regulasi dan koordinasi pelaksanaan penyiaran Indonesia seharusnya dikembangkan sebagai lembaga interaktif pelopor industri kreatif penyiaran dengan melaksanakan beragam kerja-kerja strategis dan aktivitas produktif membangun potensi masyarakat. KPI seharusnya bukan hanya lembaga executorial penyiaran melainkan partner industri penyiaran guna memajukan sosio-ekonomi industri kreatif di era digital.

Ruang lingkup pengawasan KPI seharusnya tidak terbatas pada pengawasan industri penyaiaran lokal melainkan juga pengawasan industri penyiaran premium dan moda penyiaran media sosial. KPI seringkali tergagap menghadapi konsekuensi negatif yang dihasilkan dari media sosial dengan berlindung di luar kewenangannya. Padahal, KPI memiliki kompetensi hukum untuk mengirimkan keberatan, memohon pembatasan siaran hingga penghentian penyiaran.

Formula strategis lain yang bisa dihasilkan KPI adalah melakukan mediasi penyelesaian sengketa penyiaran dengan memberikan sanksi-sanksi produktif kepada lembaga penyiaran. Efektifitas penghentian tayangan hingga pelarangan penayangan materi tertentu menjanjikan kepastian sanksi bagi tegaknya regulasi. Walaupun demikian, ada mekanisme lainnya yang lebih strategis dikembangkan yaitu sanksi edukatif dan sanksi produktif yang dimunculkan ketika sengketa penyiaran. Sebuah stasisun televisi tentu akan mengikuti keputusan komisioner KPI untuk menghentikan sebuah acara. Walaupun demikian, sanksi tersebut tidak memiliki dampak bagi masyarakat selain tidak terulangnya siaran.

Rumusan sanksi seharusnya tidak hanya bersifat pemberian hukuman melainkan juga harus bersifat restorative justice bagi kerugian yang telah dialami masyarakat. Andai kata sanksi dijatuhkan dengan merumuskan kewajiban meminta maaf secara terbuka dan keharusan melakukan edukasi keterampilan masyarakat tentu akan lebih memiliki efek jera dan memberikan manfaat bagi masyarakat.

Selain masalah sanksi, ada hal menarik yang terjadi dalam dunia penyiaran televisi. Kalangan penyedia jasa penyiaran terkesan tidak sinergis dengan dunia yang digelutinya, beragam kegiatan Corporate Social Responsibility (CSR) dunia penyiaran seringkali malah terlepas dari dunia penyiaran. Saluran televisi A misalnya melakukan kegiatan bedah rumah, saluran televisi B mengadakan operasi bibir sumbing, atau televisi $C$ yang mengadakan beasiswa bagi kalangan tidak mampu. Perbuatan tersebut tentu perbuatan mulia dan seharusnya dilakukan oleh kalangan yang mampu. Walaupun demikian, literasi media yang seharusnya bagian dari dunia keseharian mereka justru ditinggalkan. Hingga saat ini, Belum ditemukan proporsi ideal dari kalangan penyedia jasa siaran untuk melakukan pendidikan literasi media di masyarakat. Khususnya, pendidikan kreatif pembuatan siaran yang edukatif, berkualitas dan sesuai dengan nilai-nilai Pancasila, UUD NRI 1945 dan keluhuran budi pekerti Indonesia. Akibatnya, literasi media digital masyarakat nyaris tidak tergarap, masyarakat harus belajar sendiri dan mencari informasi sendiri. 